\title{
Polerowanie magnetyczno-ścierne spoin doczołowych elementów rurowych
}

\section{Magnetic polishing of butt welded pipes}

\section{Streszczenie}

W artykule opisano najistotniejsze aspekty obróbki magnetyczno-ściernej wraz ze wstępnymi badaniami dotyczącymi polerowania spoin doczołowych w elementach rurowych. Przedstawiono zarówno rozważania teoretyczne dotyczące charakteru narzędzia ściernego jak i problemy praktyczne, na które autor natknął się podczas przeprowadzania doświadczeń.

Słowa kluczowe: polerowanie; obróbka magnetycznościerna; obróbka spoin; rury spawane

\section{Abstract}

The article describes most important aspects of magnetic-abrasive machining, with preliminary studies for polishing butt welds in piping components. The paper also presents theoretical considerations regarding characteristic of the abrasive tool and the practical problems which the author encountered during the experiments.

Keywords: polishing; magnetic abrasive finishing; welds finishing; welding pipes

\section{Wstęp}

Celem klasycznego polerowania jest nadanie odpowiedniej gładkości oraz połysku przedmiotom obrabianym wykorzystując do tego metody obróbki ściernej, chemicznej lub elektrochemicznej. W ramach obróbki ściernej są stosowane narzędzia w postaci pas polerskich nakładanych na tarcze polerskie, które mogą być usytuowane w różnych konfiguracjach względem powierzchni obrabianej. Jednym z warunków, który musi być spełniony w procesie polerowania jest bezpośredni dostęp narzędzia do strefy obróbki. Uwzględniając dodatkowy ruch roboczy wykonywany przez przedmiot obrabiany implikuje to znaczne ograniczenia szczególnie w przypadku przedmiotów o skomplikowanych kształtach z obszarami trudnodostępnymi. Rozwiązaniem dla takiego problemu jest zastosowanie polerowania magnetyczno-ściernego.

\section{Podstawy obróbki magnetyczno-ściernej}

Jest to technika obróbki, która umożliwia formowanie narzędzia ściernego w wyniku oddziaływania ferromagnetycznych ziaren ściernych z zewnętrznym polem magnetycznym. W trakcie obróbki występuje kilka głównych czynników wpływających na zachowanie się narzędzia (rys 1). W zależności od charakterystyki układu generującego pole magnetyczne oraz od ruchów roboczych wykonywanych przez przedmiot składowe te mogą mieć różny wpływ na siłę ogólną. Ciężar ziaren ściernych jest stosunkowo niewielki i pomijalne mały. Siły wiskotyczne wynikają z konieczności zastosowania cieczy technologicznej, która ma za zadanie zmniejszyć siły tarcia występującego pomiędzy ziarnami jak i pomiędzy ziarnami a powierzchniami obrabianymi.

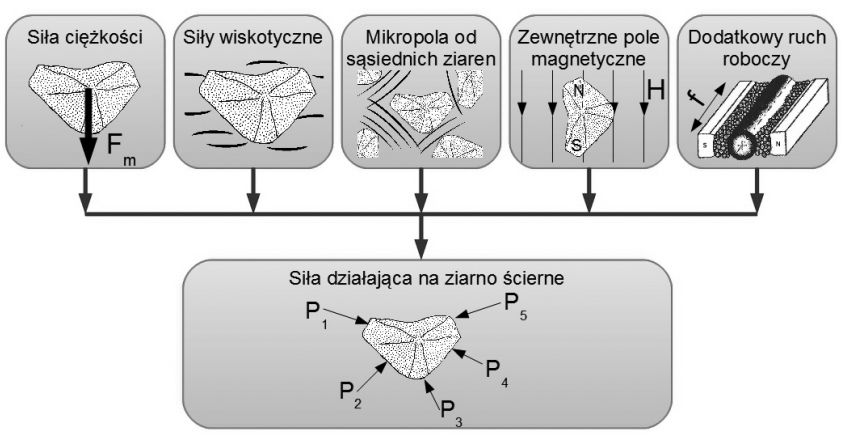

Rys. 1. Czynniki wpływające na siłę oddziałującą na ziarno ścierne Fig. 1. Factors influencing the force that acts on the abrasive grains

Aby obróbka mogła zachodzić wymagany jest dodatkowy ruch roboczy przedmiotu obrabianego lub obwodu generującego strumień magnetyczny. Ruch ten najczęściej występuje w postaci ruchu obrotowego, posuwisto-zwrotnego lub ich kombinacji.

W skład stanowiska eksperymentalnego do badań obróbki magnetyczno-ściernej wchodzi obwód magnetyczny z magnesami stałymi, korpus oraz próbka w postaci obracającej się rury spawanej doczołowo (rys. 2) [2,3]. Stanowisko posiada możliwość regulowania szerokości szczeliny

Mgr inż. Michał Marczak - Instytut Technik Wytwarzania, Politechnika Warszawska. 
obróbkowej w zakresie do $30 \mathrm{~mm}$ oraz zmianę rozkładu indukcji magnetycznej poprzez rozmieszczenie do pięciu magnesów w stosie górnym i dolnym.

Powyższe zastosowanie jest spotykane w literaturze z drobnymi różnicami jak np. rodzaj ziaren ściernch lub znaczne gabaryty stanowiska doświadczalnego $[5,7,8]$. Umieszczenie ziaren ściernych wewnątrz rury, którą następnie wprowadza się pomiędzy dwa lub więcej bieguny magnetyczne oraz nadaje dodatkowy ruch roboczy w postaci $\mathrm{np}$. oscylacji pola magnetycznego pozwala uzyskać proces mikroskrawania ich wewnętrznych powierzchni.

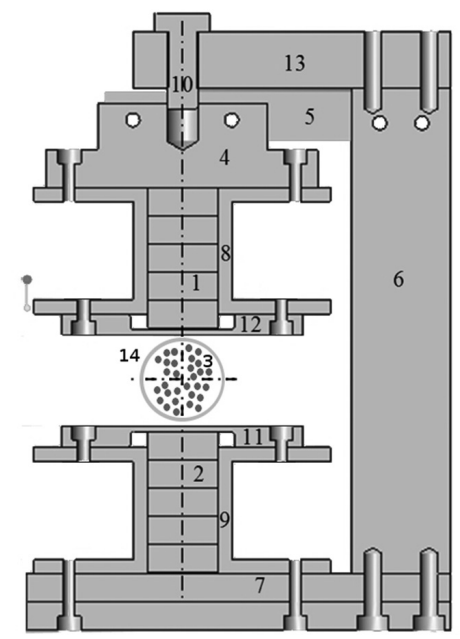

Rys. 2. Przekrój stanowiska: 1,2 - magnesy trwałe, 3 - ferromagnetyczne ziarna ścierne, 4, 5, 6, 7 - magnetowód z żeliwa, 8, 9 - tuleje utrzymujące magnesy w osi, 10 - śruba regulująca szczelinę, 11,12 - separatory, 13 - korpus, 14 - przedmiot obrabiany

Fig. 2. Cross section of experimental station: 1,2 - magnets, 3 - ferromagnetic abrasive grains, 4, 5, 6, 7 - magnetic core (iron), 8, 9-sleeve axial, 10 - adjusting screw, 11, 12 - separators, 13 - body, 14 - workpiece

Efektem jest możliwość polerowania powierzchni trudno dostępnych, ciężka do zrealizowania innymi technikami obróbkowymi. Autor proponuje sprawdzenie możliwości przeprowadzenia powyższej metody dla spoin rur spawanych doczołowo wykonanych $z$ materiałów niemagnetycznych [4]. Celem tego zabiegu jest oczyszczenie powierzchni trudnodostępnych do jakich zaliczają się wewnętrzne obszary złączy doczołowych $[1,6]$. Idea jest zbliżona z tą różnicą, że w strefie obróbki usytuowana jest spoina, która została poddana polerowaniu magnetyczno-ściernemu dla różnych czasów obróbkowych (rys. 3). Celem tego zabiegu było usunięcie warstwy tlenków metali, ewentualnych rozprysków oraz innych niezgodności spawalniczych w szczególności określających stan powierzchni spoiny.

Próbki do badań zostały wykonane ze stopu aluminium AW-6060 (PA38 - niemagnetycznego), który następnie spawano doczołowo elektrodą nietopliwą w osłonie argonu (metoda TIG - Tungsten Inert Gas). Tak przygotowane próbki obrabiano

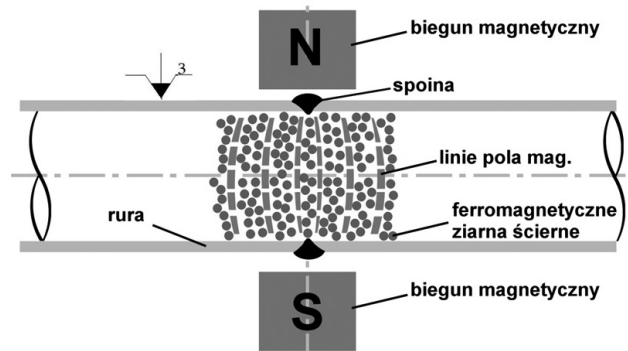

Rys. 3. Schemat wygładzania magnetyczno-ściernego spoin doczołowych elementów rurowych

Fig. 3. Scheme of magnetic-abrasive polishing of butt joint welding pipes na stanowisku do obróbki magnetyczno-ściernej zainstalowanym na tokarce ze średnią prędkością obróbki 80 m/min (rys. 4).
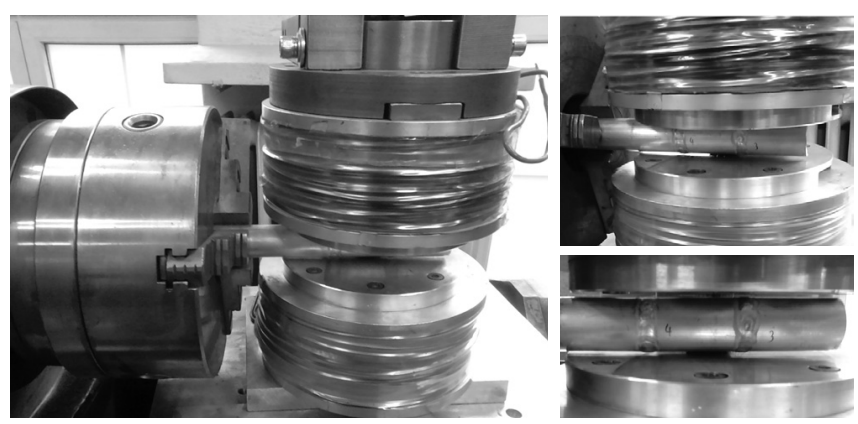

Rys. 4. Widok stanowiska badawczego do wygładzania spoin doczołowych elementów rurowych

Fig. 4. View of experimental station for polishing the butt joint welding pipes

Próby przeprowadzono na rurach o średnicy $ø 30 \mathrm{~mm}$ i grubości ścianki $2 \mathrm{~mm}$ dla następujących czasów obróbkowych: $10,15,20,30 \mathrm{~min}$. W tym celu wykorzystano lite, ferromagnetyczne ziarna ścierne Fe - Tic 315/200 z cieczą technologiczną w postaci nafty dielektrycznej. Po przeprowadzeniu doświadczeń i dokonaniu pomiarów nie stwierdzono ubytku masy próbek po obróbce.

W obszarze otaczającym spoinę, a zawierającym się w zasięgu narzędzia ściernego zaobserwowano poprawę parametrów chropowatości (tabl. II).

Tablica I. Wybrane widoki lica spoiny przed i po obróbce dla poszczególnych czasów

Table I. Selected view of welds before and after machining for each times

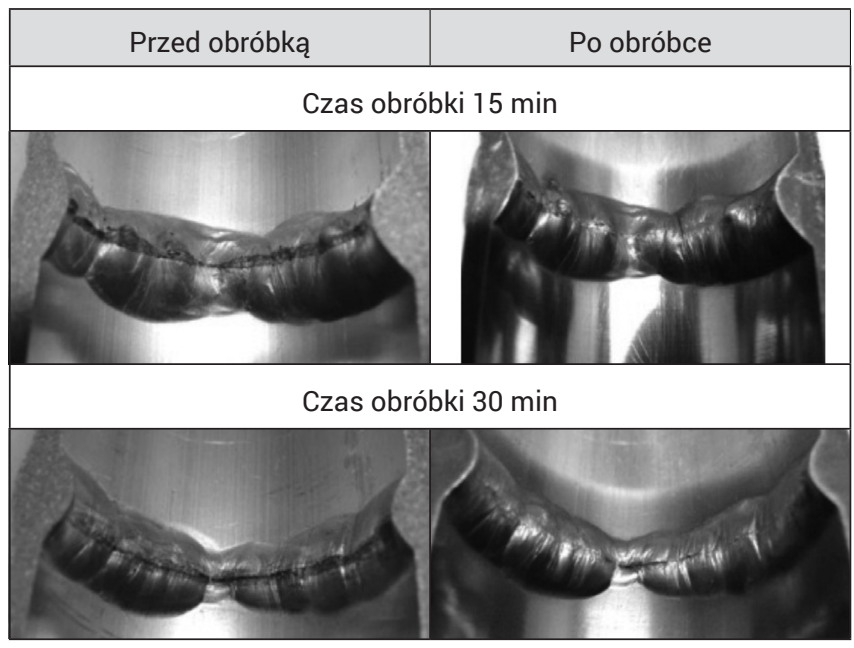

Tablica II. Wartości parametrów chropowatości przed i po obróbce dla poszczególnych czasów w obszarze działania narzędzia ściernego Table II. Roughness value before and after process for each time machining in area of the acting abrasive tool

\begin{tabular}{|c|c|c|c|c|c|}
\hline & \multirow{2}{*}{$\begin{array}{c}\text { Przed } \\
\text { obróbką }\end{array}$} & \multicolumn{4}{|c|}{ Po obróbce [min] } \\
\hline & & 10 & 15 & 20 & 30 \\
\hline $\mathrm{Ra}[\mu \mathrm{m}]$ & 0,34 & 0,34 & 0,34 & 0,34 & 0,34 \\
\hline $\mathrm{Rq}[\mu \mathrm{m}]$ & 0,29 & 0,29 & 0,29 & 0,29 & 0,29 \\
\hline $\mathrm{Rz}[\mu \mathrm{m}]$ & 0,3 & 0,3 & 0,3 & 0,3 & 0,3 \\
\hline Ry $[\mu \mathrm{m}]$ & 0,21 & 0,21 & 0,21 & 0,21 & 0,21 \\
\hline $\mathrm{Sm}[\mu \mathrm{m}]$ & 0,52 & 0,52 & 0,52 & 0,52 & 0,52 \\
\hline
\end{tabular}




\section{Wnioski}

W wyniku obróbki zaobserwowano widoczne wygładzenia lica spoin czołowych oraz oczyszczenie z nalotów powstałych w wyniku spawania. Efekt polerowania pozwolił uzyskać wybłyszczenie powierzchni w obszarze spoiny. Spadek chropowatości sięga 35\% wartości względem początkowej powierzchni. Z kolei zaskoczeniem są wyniki pomiaru uzyskane dla parametru Sm, które w podobnych eksperymentach znacząco zwiększały swoją wartość [4].

Otrzymane rezultaty obróbki pozwalają na zastosowanie opracowanej technologii do oczyszczania złączy spawanych elementów rurowych stosowanych np. w przemyśle spożywczym (po uprzednim usunięciu ziaren ściernych przed eksploatacją). W celu skrócenia czasu procesu dalsze badania powinny być prowadzone z zastosowaniem ferromagnetycznych ziaren ściernych ziaren zarówno wewnątrz jak i na zewnątrz elementu obrabianego. Zabieg ten może zwiększyć przewodność magnetyczną szczeliny obróbkowej, co z kolei wpłynie na indukcję w jej wnętrzu, od której zależy siła, jaka działa na pojedyncze ziarno ścierne.

\section{Literatura}

[1] Ambroziak A., Białucki P., Derlukiewicz W., Lange A., "Ocena jakości złączy spawanych ze stali x6Cr17 i x5CrNi18-10 stosowanych w wymiennikach ciepła", Przegląd Spawalnictwa Vol.85/No.6 (2013).

[2] Dąbrowski L., Marczak M., Onszczuk D., „Wpływ parametrów obróbki na chropowatość powierzchni przedmiotów po obróbce magnetycznościernej", Mechanik 8/9 2013

[3] Marczak M., „Opracowanie i weryfikacja modelu numerycznego stanowiska do obróbki magnetyczno-ściernej", Mechanik 12/2013, str. 1040.

[4] Marczak M., Świercz R., Oniszczuk D., „Polerowanie magnetycznościerne spoin doczołowych elementów rurowych", Inżynieria warstwy wierzchniej, 2014, IBEN Gorzów Wielkopolski, ISBN 978-83-64249-17-4.
[5] Palwinder S., Partap S. S., Lakhvir S., "Internal finishing of cylindrical pipes using sintered magnetic abrasive",International Journal of Engineering Science and Technology (IJEST), Vol. 3, No. 7, July 2011.

[6] Pietras A., Weglowska A., Rams B., Węglowski M. S., „Nowa technologia zgrzewania tarciowego rury z pokrywą", Przegląd Spawalnictwa Vol.83/No.11 (2011)

[7] Wantuch E. T., „Podstawy technologii magnetościernej”, WNT Warszawa 2000.

[8] Yamaguchi H., Kang J., Hashimoto F., „Metastable austenitic stainless steel for magnetic abrasive finishing", CIRP Annals - Manufacturing Technology, 60 (2011) 339-342. 